\title{
THE DEVELOPMENT PATTERN OF IGF-1 (INSULIN- LIKE GROWTH FACTOR-1) PROTEIN EXPRESSION IN BREAST MUSCLE OF BROILER CHICKENS
}

\author{
Z. Kanački, S. Stojanović, G. Ušćebrka, D. Žikić \\ Faculty of Agriculture, Trg Dositeja Obradovića 8, 21000 Novi Sad, Republic of Serbia \\ Corresponding author: zdenkovet@yahoo.com \\ Original scientific paper
}

\begin{abstract}
It is proved that the protein expression of IGF-1 is detected in several tissues including liver, brain, eye, lung, pancreas and muscle. This growth factor exerts autocrine and paracrine effect during embryonic and postnatal development and is involved in muscle development. The aim of this study was to determine the level of protein expression of IGF-1 in breast muscle during embryonic and postnatal development of broiler chickens. For the experiment were used fertilized eggs and broiler chickens of heavy hybrid "Ross 308", originating from parent flock at the age of 54 weeks. Samples of breast muscle were taken from embryos during the 15th and 19th day of embryonic development and 3rd and 21 st day of postnatal development from 5 birds in each age category. From all of the embryos and chickens the right side of the brest muscles were individually sampled. The muscle tissue was macerated and then homogenized in buffer with protease inhibitors. After that immunoprecipitation, electrophoresis and transfer the Western blot analysis were performed on all samples. For visualization of proteins the membranes were incubated in chemiluminescent substrate. The results indicate statistically significant increase in protein expression of IGF-1 in breast muscle on the $19^{\text {th }}$ day of embryonic development and $3^{\text {rd }}$ of postnatal development in compared to $15^{\text {th }}$ day of embryonic development ( $\mathrm{p}<0,05$ compared to $19^{\text {th }}$ day of embryonic development and $\mathrm{p}<0,01$ compared to the $3^{\text {rd }}$ day of postnatal development). After the $3^{\text {rd }}$ day of postnatal development the protein expression was at the same level until the $21^{\text {st }}$ day of postnatal development.
\end{abstract}

Key words: IGF-1, breast muscle, broiler chickens

\section{Introduction}

It has been shown that insulin-like growth factor-1 (IGF-1), in birds, is essential for normal growth and development (Proudman et al., 1994). The origin of IGF-1 in muscle may be twofold. IGF-1 may be derived from increased synthesis in the liver under the effect of growth hormone and, more significant, 
may be of local origin, and manifest autocrine or paracrine effect (Halevy et al., 2001). Alternatively, the effects of IGF-1 may be, at least partially, mediated by hormones such as thyroid hormones (Adams et al., 2000). It has been shown that IGF-1 stimulates proliferation of satellite cells in chickens (Duclos et al., 1991; Hodik et al., 1997).

Growth factors in muscle define the direction of development of muscle cells in the direction of cell proliferation or the direction of cell differentiation. The same growth factor can stimulate the muscle cells in both of these processes, but through different systems of secondary messengers in the cell. The activation of phosphoinositide 3-kinase (PI3K) pathway of secondary messengers stimulates the differentiation of myoblasts, while activation of mitogen-activated protein kinase (MAPK) pathway stimulates the proliferation and inhibits differentiation of myoblasts (Halevy and Cantley, 2004).

IGF-1 plays an important role in the metabolism of carbohydrates, fats and protein in adipose tissue, skeletal muscle and liver. IGF-1, in skeletal muscle cells, stimulates protein synthesis and the uptake of glucose (LeRoith and Yakar, 2007). In this way, IGF-1 can significantly affect the chemical composition and progressive loss of moisture from the meat.

The aim of this study was to determine the level of protein expression of IGF-1 in breast muscle during embryonic and postnatal development of broiler chickens.

\section{Materials and Methods}

For this trial we have used the fertilized eggs of heavy hybrid "Ross 308". The average egg weight was $66.5 \mathrm{~g}$ and ranged from $63.5 \mathrm{~g}$ to $69 \mathrm{~g}$. After the rest period the eggs were deposited in to the incubator. Temperature and relative humidity were controlled by analog device (Veb, Berlin, Germany). The humidity in all incubators was maintained between $50 \%$ and $60 \%$ until the $18^{\text {th }}$ day of embryonic development and up to $75 \%$ from $19^{\text {th }}$ day of embryonic development until the end of incubation. After hatching, drying and resting for 24 hours, the broilers were packed into transport boxes and transferred to the facility for fattening (the floor system with boxes). The conditions (temperature, humidity, lighting, density) were adapted in accordance with requirements of this hybrid (Halevy et al., 2001). Chickens were vaccinated based on a regular vaccination program against Newcastle disease and infectious bursal disease, and throughout the experiment were under constant veterinary supervision.

During the production cycle broilers were fed ad libitum in three phases. From $1^{\text {st }}$ to $13^{\text {th }}$ day the diet was with $22 \%$ of proteins (starter), from $14^{\text {th }}$ to $34^{\text {th }}$ day the diet was with $19 \%$ of proteins (grower) and from $35^{\text {th }}$ day until the end of the production cycle ( $42^{\text {nd }}$ day) the diet was with $18 \%$ of proteins (finisher). 
The breast muscle samples for Western blot analysis were taken from the embryo during the $15^{\text {th }}$ and $19^{\text {th }}$ day of embryonic development, and during the $3^{\text {rd }}$ and the $21^{\text {st }}$ day of postnatal development. Samples of breast muscle were taken from 5 individuals in each age category. From all of the embryos and chickens the right side of the breast muscles were individually sampled. The samples were taken from the right side of the breast and then frozen in liquid nitrogen.

The tissue was macerated, and then homogenized in radio immune precipitation buffer with protease inhibitors (F. Hoffmann-La Roche Ltd. Basel, Swiss), three times in ten seconds intervals with ten second pauses. The sonification of samples was performed on $10 \mathrm{kHz}$, three times in fifteen seconds intervals with fifteen seconds pauses. The sample was then centrifuged in Beckham ultracentrifuge (Beckham Ultima TL, Fullerton, CA, USA), 90 minutes at $85000 \mathrm{~g}$. The obtained supernatants were used for Western blot analysis.

To determine the protein expression of IGF-1, $100 \mathrm{mg}$ of tissue homogenate protein was precipitated with rabbit polyclonal anti-IGF-1 antibody (Abcam, Cambridge, UK) with final dilution of 1:50. Immune complexes were precipitated adding protein A / G-Sepharose (the initial amount of $100 \mathrm{mg}$ protein per $20 \mu \mathrm{l}$ of purified Sepharose) and were incubated for 2 hours at $4{ }^{\circ} \mathrm{C}$. After centrifugation ( 5 seconds at $14000 \mathrm{~g}$ ) pellet was rinsed three times with iced buffer. The obtained residue proteins were used for SDS-polyacrylamide electrophoresis and immunoblotting.

The proteins were separated by molecular mass in a BioRad Mini-Protean III system (BioRad, Mississauga, Ontario). Gels used to separate proteins were different depending on the molecular weight of the proteins and a gel for concentration was $5 \%$ (5\% acrylamide / bisacrylamide, $0.1 \%$ SDS; $0.125 \mathrm{M}$ Tris, $\mathrm{pH}$ 6.8). Polymerization of gels was enabled by adding $0.05 \%$ ammonium persulfate and $0.033 \% \mathrm{~N}, \mathrm{~N}, \mathrm{~N}^{\prime}, \mathrm{N}^{\prime}$-tetramethyl-ethylenediamine. The buffer for reservoirs was consisted of $0.192 \mathrm{M}$ glycine, $0.1 \%$ SDS and $0.025 \mathrm{M}$ Tris, $\mathrm{pH} 8.3$. The equal volume of sample buffer (4\% SDS, 20\% glycerol, $10 \% \quad \beta$ mercaptoethanol; $0125 \mathrm{M}$ Tris, $\mathrm{pH}$ 6.8; $0.025 \%$ brome phenol blue) was added in to the specific volume of protein solution. Samples were further denatured by boiling for 5 minutes at $95{ }^{\circ} \mathrm{C}$. The proteins from the sample and the protein marker were poured to the gels in order to determine the molecular weight (Fermentas International, Inc., Burlington,Canada). Electrophoresis lasted for 6090 minutes at constant voltage of $120 \mathrm{~V}$. After electrophoresis, the gels were used for Western blot.

Proteins were transferred from gels to polyvinylidene fluoride membrane Hybond-P (Amersham Pharmacia Biotech). The membranes were activated in methanol (10 seconds). Membranes and gels were packaged and placed in tanks with transfer buffer ( $0.192 \mathrm{M}$ glycine, $20 \%$ methanol and $0.025 \mathrm{M}$ Tris, $\mathrm{pH} 8.3$ ). The transfer of proteins from gels to membranes was carried out at constant voltage of $100 \mathrm{~V}$ for 60 minutes. The success of the transfer was confirmed with $5 \%$ 
Ponceau S color dissolved in glacial acetic acid. Membranes were discolored by rinsing in distilled water and then incubated for one hour at room temperature in serum to block free sites on the membrane - $5 \%$ bovine serum albumin in Trisborate buffer supplemented with Tween detergent (TBS-T: $0.2 \mathrm{M}$ Tris, $1.5 \mathrm{M}$ $\mathrm{NaCl}, 0.05 \%$ Tween $20, \mathrm{pH}$ 7.4). After blocking the membranes were incubated with primary antibody.

Western blot was performed in a quantitative manner (Tienrungroj et al., 1987). Antibody and concentration used in this experiment is: Antibody IGF-1 (ab9572), the concentration of $0.2 \mathrm{mg} / \mathrm{ml}$. After blocking, the membranes were incubated with appropriate primary antibodies diluted in 5\% bovine serum albumin, overnight at $4{ }^{\circ} \mathrm{C}$. After incubation and washing away excess antibody, the membranes were incubated with secondary antibody obtained by immunization of goats with a rabbit immunoglobulin G (IgG) (Santa Cruz Biotechnology, Inc.), diluted 1:2000 (antibody: 5\% bovine serum albumin), 2 hours at room temperature. After incubation, the membranes were rinsed with TBS solution for 30 minutes at room temperature. For visualization of proteins the membrane were incubated in luminol, with the addition of $\mathrm{H}_{2} \mathrm{O}_{2}$ for three minutes. After that, the X-ray films (Hyperfilm, Amerscham Pharmacia Biotech) were subjected to membranes (0.5-2 minutes). The films were developed, scanned and used for quantification of protein bands.

Data are presented as means \pm SEM. Data were analyzed by Tukey test to separate means by using Graph Pad Software 3.03 program (GraphPad Prism 3.03, GraphPad Software Inc., San Diego, CA, USA).

\section{Results and Discussion}

It is relatively difficult to draw definitive conclusions about changes in concentration of IGF-1 during development in birds. Generally it can be concluded that concentrations of IGF-1 in plasma, during embryonic development in birds, expressed a clear single-phase profile. In chicken embryos, the blood plasma concentration of IGF-1 increases from $9^{\text {th }}$ day of incubation and reaches a peak at $15^{\text {th }}$ day of incubation and then gradually decreases (Kikuchi et al., 1991; Robcis et al., 1991; Scanes et al., 1997). In addition, there is evidence that the concentration increases again later in the development (McMurty et al., 1994). Ontogenetic profile of the concentration of circulating IGF-1 in chickens was given by Hybrechts et al. (1985), McGuiness and Cogburn (1990) and Redecki et al. (1997).

Unlike mammals, where the concentration of IGF-1 in blood plasma directly related to the GH-dependent synthesis in the liver (Kind et al., 1995), in birds, this is only partly the case. This is based on the fact that in the liver of chicken embryos were not found the significant levels of mRNA (messenger ribonucleotid acid) for IGF-1 (Kikuchi et al., 1991, Burnside and Cogburn, 1992). Also, the concentration of circulating IGF-1 decreases after hypophiseoctomy, but 
only on the half of the initial value (Hybrectes et al., 1985) and a GH (growth hormone) therapy only partially establishes the initial level in the circulation (Scanes et al., 1986). A similar situation is found in dwarfs that lack functional GH receptors, where the level of IGF-1 in circulation decreased by about $50 \%$ (Hybrectes et al., 1985). In mammals, GH deficiency reduces the levels of IGF-1 in the circulation for more than $90 \%$ (Glassock et al., 1990). Houston and O'Neill (1991) show that the liver cells are releasing IGF-1 in the presence of GH and insulin.

The explanation may be that the synthesis of IGF-1 in the liver, partially independent of GH in birds, and that the liver is not the only source of IGF-1. There is evidence that IGF-1 is synthesized in several other tissues including brain, eye, lung, pancreas, and muscles (Serna et al., 1996, Tanaka et al., 1996). This synthesis of IGF-1 may point to its local (autocrine or paracrine) and endocrine effects. In addition, the mere synthesis of IGF-1 does not mean, by itself, that it is entirely released into the circulation. There is indirect evidence that IGF-1, in the circulation, originates from the different tissues (Scanes, 1997). Because IGF-1 has local, as well as systematic effects, it is important to measure the protein expression of this growth factor in each tissue individually.

The protein expression of IGF-1 was detected in breast muscle tissue during the embryonic and postnatal development. The level of protein expression was increasing from the 15th day of embryonic development until the 3rd day of postnatal development and remained at that level until the 21 st day of postnatal development. The protein expression of IGF-1 is shown in Table 1.

Table 1 Protein expression of IGF-1 in the breast musculature

\begin{tabular}{|c|c|}
\hline Age & IGF-1 expression ${ }^{1}$ \\
\hline \multicolumn{2}{|l|}{ Prenatal } \\
\hline 15 th day & $100 \pm 11$ \\
\hline 19th day & $132 \pm 13^{*}$ \\
\hline \multicolumn{2}{|l|}{ Postnatal } \\
\hline 3rd day & $240 \pm 21 * *$ \\
\hline 21st day & $242 \pm 22 * *$ \\
\hline
\end{tabular}

${ }^{1} \%$ compared to the 15 th day of embryonic development, ${ }^{*} \mathrm{p}<0,05,{ }^{* *} \mathrm{p}<0,01$

The results indicate statistically significant increase in protein expression of IGF-1, in breast muscle, during the late embryonic development and early postnatal development. On the $19^{\text {th }}$ day of embryonic development and $3^{\text {rd }}$ of postnatal development in compared to $15^{\text {th }}$ day of embryonic development $(\mathrm{p}<0,05$ compared to $19^{\text {th }}$ day of embryonic development and $\mathrm{p}<0,01$ compared to the $3 \mathrm{rd}$ day of postnatal development). After the 3rd day of postnatal development the 
protein expression was at the same level until the $21^{\text {st }}$ day of postnatal development.

Growth factors in muscle define the direction of development of muscle cells in the direction of cell proliferation or the direction of cell differentiation. The same growth factor can stimulate the muscle cells in both of these processes, but through different systems of secondary messengers in the cell (Halevy and Cantley 2004).

The lower levels of IGF-1 in muscle, in the earlier stages of development, may be essential for achieving better results at the end of the production cycle. The IGF-1 in muscle tissue induces differentiation process, while some factors such as FGF and HGF inhibit this process, and stimulate cell proliferation (Barton-Davis et al., 1999; Ganong, 1995). Lower levels of IGF-1 in muscle, in the early period of development, enable proliferation of satellite cells. The increased levels of IGF-1, in later stages of development, stimulate the differentiation and hypertrophy. This may be the basis of the mechanism through which different treatments, during the embryonic development, stimulates the body weight gain and increase of protein content in meat (Halevy et al., 2006).

\title{
Conclusion
}

The results indicate statistically significant increase in protein expression of IGF-1 in breast muscle on the $19^{\text {th }}$ day of embryonic development and $3^{\text {rd }}$ of postnatal development in compared to $15^{\text {th }}$ day of embryonic development $(\mathrm{p}<0,05$ compared to $19^{\text {th }}$ day of embryonic development and $p<0,01$ compared to the $3 \mathrm{rd}$ day of postnatal development). After the 3rd day of postnatal development the protein expression was at the same level until the $21^{\text {st }}$ day of postnatal development.

\section{Acknowledgment}

This work was a part of the project "Sustainable conventional and revitalized traditional production of poultry meat and eggs with added value" (TR 31033) funded by the Ministry of Education, Science and Technological Development of the Republic of Serbia.

\section{Razvojni obrazac proteinske ekspresije IGF-1 (faktora rasta nalik insulinu - 1) u grudnim mišićima brojlerskih pilića}

\author{
Z. Kanački, S. Stojanović, G. Ušćebrka, D. Žikić
}




\section{Rezime}

Dokazana je ekspresija IGF-1 u više tkiva uključujući jetru, mozak, oči, pluća, pankreas i muskulaturu. Ovaj faktor rasta ispoljava autokrino i parakrino delovanje tokom embrionalne i postnatalne faze razvoja i uključen je u proces razvoja mišića. Cilj ovog rada je bio da se utvrdi razvojni obrazac proteinske ekspresije IGF-1 u grudnim mišićima brojlerskih pilića tokom embrionalne i postnatalne faze razvoja. Za ogled su korišćena oplođena jaja i brojlerski pilići teškog hibrida "Ross 308", poreklom od roditeljskog jata u uzrastu od 54 nedelje. Uzorci grudnih mišića su uzeti od embriona tokom 15. i 19. dana embrionalnog razvoja i 3. i 21. dana postnatalnog razvoja od 5 jedinki u svakom uzrastu. Od svih embriona i pilića pojedinačno je uzet uzorak sa desne polovine grudnih mišića. Mišićno tkivo je macerirano a zatim homogenizovano u puferu sa inhibitorima proteaza. Posle imunoprecipitacije, elektroforeze i transfera na svim uzorcima je izvršena Western blot analiza. $\mathrm{Za}$ vizuelizaciju proteina membrane su inkubirane sa hemiluminescentnim substratom. Rezultati ukazuju na statistički značajno povećanje proteinske ekspresije IGF-1 u grudnim mišićima tokom 19. dana embrionalnog razvoja i 3. dana postnatalnog razvoja u poređenju sa 15. danom embrionalnog razvoja $(\mathrm{p}<0,05 \mathrm{u}$ poređenju sa 19 . danom embrionalnog razvoja $\mathrm{i}$ $\mathrm{p}<0,01$ u poređenju sa 3 . danom postnatalnog razvoja). Nakon 3. dana postnatalnog razvoja proteinska ekspresija je bila na istom nivou do 21. dana postnatalnog razvoja.

\section{References}

ADAMS, G.R., MCCUE S.A.,. BODELL P.W, ZENG M., BALDWIN K.M. (2000): Effects of spaceflight and thyroid deficiency on hind limb development. I. Muscle mass and IGF-I expression. Journal of Applied Physiology 88: 894-903.

BARTON-DAVIS, E.R., SHOTURMA D.I., SWEENEY H.L (1999): Contribution of satellite cells to IGF-I induced hypertrophy of skeletal muscle. Acta Physiologica Scandinavica 167: 301-305.

BURNSIDE, J., COGBURN, L.A. (1992): Developmental expression of hepatic growth hormone receptor and insulin-like growth factor-I mRNA in the chicken. Mol Cell Endocrinol 89: 91-96.

DUCLOS, M.J., WILKIE R.S., GODDARD C. (1991): Stimulation of DNA synthesis in chicken muscle satellite cells by insulin and insulin-like growth factors: evidence for exclusive mediation by a type-I insulin-like growth factor receptor. J. Endocrinol. 128: 35-45.

GANONG, W.F. (1995): Excitible tissue: Muscle. In: Review of Medical 
Physiology. 17th ed. Norwalk, CT: Appleton and Lange, pp 56-67.

GLASSOCK, G.E, GELBER S.E., LAMSON G., MCGEE-TEKULA R., ROSENFELD R.G. (1990): Pituitary control of growth in the neonatal rat: Effects of neonatal hypophysectomy on somatic and organ growth, serum insulin-like growth factors (IGF)-I and -II levels, and expression of IGF binding proteins. Endocrinology 127: 1792-1803.

HALEVY, O., CANTLEY L.C. (2004): Differential regulation of the phosphoinositide 3-kinase and MAP kinase pathways by hepatocyte growth factor vs. insulin-like growth factor-I in myogenic cells. Experimental cell research, 297: 224-234.

HALEVY, O., KRISPIN A., LESHEM Y., MCMURTRY J.P., YAHAV S. (2001): Early-age heat exposure affects skeletal muscle satellite cell proliferation and differentiation in chicks. American Journal of Physiology 281: R302-R309.

HALEVY, O., YAHAV S., ROZENBOIM I.. (2006): Enhancement of meat production by environmental manipulations in embryo and young broilers World's Poultry Science Journal, 62: 485-497.

HODIK, V., METT M., HALEVY O. (1997): Mutual effects of growth hormone and growth factors on chicken satellite cells. General and Comparative Endocrinology 108: 161-170.

HOUSTON B., O'NEILL I.E. (1991): Insulin and growth hormone act synergistically to stimulate insulin-like growth factor-I production by cultured chicken hepatocytes. Journal of Endocrinology 128: 389-393.

HUYBRECHTS, L.M., KING D.B., LAUTERIO T.J., MARSH J., SCANES C.G. (1985): Plasma concentrations of somatomedin-C in hypophysectomized, dwarf and intact growing domestic fowl as determined by heterologous radioimmunoassay. J. Endocrinol. 104: 233-239.

KIKUCHI, K., BUONOMO F.C., KAJIMOTO Y., ROWEIN P. (1991): Expression of insulin-like growth factor-I during chicken development. Endocrinology 128: 1323-1328.

KIND, K.L., OWENS, J.A., ROBINSON, J.S., QUINN, K.J., GRANT, P.A., WALTON, P.E., GILMOUR, R.S., OWENS, P.C. (1995): Effect of restriction of placental growth on expression of IGFs in fetal sheep: relationship to fetal growth, circulating IGFs and binding proteins. Journal of Endocrinology 146: 23-34.

LEROITH, D., YAKAR S. (2007): Mechanisms of Disease: metabolic effects of growth hormone and insulin-like growth factor 1. Nature Reviews Endocrinology 3: 302-310.

MCGUINNESS, M.C., COGBURN L.A. (1991): Response of young broiler chickens to chronic injection of recombinant-derived human insulin-like growth factor-I. Domes. Anim. Endocrinol. 8: 611-620.

MCMURTRY, J.P., FRANCIS G.L., UPTON F.Z., ROSSELOT G., BROCHT D.M., (1994): Developmental changes in chicken and turkey insulin-like growth factor-I (IGF-I) studied with a homologous radioimmunoassay for chicken IGF-I. 
J. Endocrinol. 142: 225-234.

PROUDMAN, J.A., MCGUINNESS M.C., KRISHNAN K.A., COGBURN L.A. (1994): Endocrine and metabolic responses of intact and hypophysectomized turkey poults given a daily injection of chicken growth hormone. Comp. Biochem. Physiol.109C: 47-56.

Radecki, S.V. and Scanes, C.G. (1997) The hypothalamo-pituitary growth hormone (GH)-insulin-like factor (IGF) axis: coupling and uncoupling. In: Harvey S, Etches R, editors. Perspectives in Avian Endocrinology. Journal of Endocrinology, London.

ROBCIS, H.L., CALDES T., DE PABLO F. (1991): Insulin-like growth factor-I levels show a mid-embryogenesis peak in chicken that is absent in growthretarded embryos cultured ex ovo. Endocrinology, 128: 1895-1901.

SCANES, C.G., DUYKA D.R., LAUTERIO T.J., BOWEN L.M., HUYBRECHTS L.M., BACON W.L., KING D.B. (1986): Effect of chicken growth hormone, triiodothyronine and hypophysectomy in growing domestic fowl. Growth 50: 12-31.

SCANES, C.G., R.C. THOMMES, RADECKI S.V., BUONOMO F.C., WOODS J.E. (1997): Ontogenic changes in the circulating concentrations of insulin-like growth factor (IGF)-I, IGF-II and IGFbinding proteins in the chicken embryo. Gen. Comp. Endocrinol. 106: 265-270.

SERNA, J., GONZALEZ-GUERRERO P.R., SCANES C.G., PRATI M., MORREALE G., DE PABLO F.F. (1996): Differential and tissue specific regulation of (pro) insulin and insulin-like growth factor-I mRNAs and levels of thyroid hormones in growth-retarded embryos. Growth Regulation 6: 73-82.

TANAKA M., HAYASHIDA Y., SAKAGUCHI K., OHKUBO T., WAKITA M., HOSHINO S., NAKASHIMA K. (1996): Growth hormone-independent expression of insulin-like growth factor I messenger ribonucleic acid in extrahepatic tissues of the chicken. Endocrinology 137: 30-34.

TIENRUNGROJ, W., SANCHEZ, E.R., HOUSLEYS, P.R., HARRISONLL, R.W., PRATT, W.B. (1987): Glucocorticoid Receptor Phosphorylation, Transformation, and DNA Binding. The Journal of Biological Chemistry 262, 36: 17342-17349. 